PERM JOURNAL OF PETROLEUM AND MINING ENGINEERING

ВЕСТНИК ПНИПУ. ГЕОЛОГИЯ. НЕФТЕГАЗОВОЕ И ГОРНОЕ ДЕЛО

ISSN 2224-9923

Volume / Tom 18 №2, 2018

http://vestnik.pstu.ru/geo/

УДК 622.276:553.98:551.72

Article / Статья

(C) PNRPU / ПНИПУ, 2018

\title{
MODELING THE STRUCTURE AND FORMATION OF THE OIL AND GAS POTENTIAL OF RIPHEAN-VENDIAN DEPOSITS THAT BELONG TO NORTH-EAST REGIONS OF THE VOLGA-URAL OIL AND GAS PROVINCE
}

\section{Svetlana E. Bashkova, Tatyana V. Karaseva, Inna A. Kozlova', Andrey N. Bashkov²}

Kama Research Institute for Complex Studies of Deep and Ultra-Deep Wells (15 Krasnoflotskaya st., Perm, 614016, Russian Federation)

Perm National Research Polytechnic University (29 Komsomolskiy av., Perm, 614990, Russian Federation)

${ }^{2}$ AVK Invest LLC (9 Lodygina st., office 10, Perm, 614090, Russian Federation).

\section{МОДЕЛИРОВАНИЕ СТРОЕНИЯ И ФОРМИРОВАНИЯ НЕФТЕГАЗОНОСНОСТИ РИФЕЙ-ВЕНДСКИХ ОТЛОЖЕНИЙ СЕВЕРО-ВОСТОЧНЫХ РАЙОНОВ ВОЛГО-УРАЛЬСКОЙ НЕФТЕГАЗОНОСНОЙ ПРОВИНЦИИ}

\section{С.Е. Башкова, Т.В. Карасева, И.А. Козлова ${ }^{1}$, А.Н. Башков ${ }^{2}$}

Камский научно-исследовательский институт комплексных исследований глубоких и сверхглубоких скважин (614016, Россия, г. Пермь, ул. Краснофлотская, 15)

Пермский национальный исследовательский политехнический университет (614990, Россия, г. Пермь, Комсомольский пр., 29) ${ }^{2} \mathrm{OOO}$ «АВК Инвест» (614090, Россия, г. Пермь, ул. Лодыгина, 9, оф. 10)

Received / Получена: 28.09.2018. Accepted / Принята: 24.10.2018. Published / Опубликована: 30.11.2018

Key words:

Volga-Ural oil and gas province, Riphean and Vendian sediments, basin modeling, oil and gas source rocks, paleotemperature conditions, vitrinite reflectivity, main oil generation zone, main gas prospects of oil and gas potential.

Ключевые слова: Волго-Уральская нефтегазоносная провинция, рифейские и вендские отложения, бассейновое моделирование, нефтегазоматеринские породы, палеотемпературные условия, отражательная способность витринита, главная зона нефтеобразования, главная зона газообразования, формирование и перспективы нефтегазоносности.
The paper is devoted to the urgent problem of studying the prospects of the oil and gas potential of Riphean-Vendian sediments of poorly studied areas such as northeastern regions of the Volga-Ural oil and gas province. The paper presents the characteristic of the lithological and stratigraphic features of the structure of Riphean and Vendian deposits in the northeastern part of the Volga-Ural oil and gas province. Particular attention is paid to the basin modeling of well sections that did not fully passed through the Riphean-Vendian complex of rocks. That allows to predict oil and gas generation processes. During the research sections of three wells were modelled. Wells Keltmenskaya-1, Krasnovisherskaya-18, Borovitskaya-624 revealed Upper Proterozoic rocks in the north-east of the Perm region and the Komi Republic. Procedure features of the used software systems, phasing of the research, including gathering and input of initial data, proces (n) formation and oil and gas accumulation of Riphean and Vendian sediments of this territory are associated with insufficient information on the structure and composition of sediments, incomplete drilling of ancient sediments in wells and inconsistent geophysical data. In addition, the complexity of the reconstruction lies in the lack of information about geothermal conditions of sections, numerous interruptions in sedimentation and erosion of sediments. According to simulation results, most of the Riphean-Vendian sedimentary section is located in the main zone of oil generation. The research conducted allowed the authors to conclude that there are increased prospects to discover oil hydrocarbons in a wide range of depths in the areas where the Krasnovisherskaya-18 and Borovitskaya-624 wells are drilled. There is a little likelihood that gaseous hydrocarbons can be found in the section. Conducted research and obtained results pose a problem for the development of geological exploration in the poorly studied areas of the northeast of the Volga-Ural oil and gas province. First of all, that corresponds to reference-parametric drilling together with the zonal-regional geophysical studies.

Данная статья посвящена актуальной проблеме изучения перспектив нефтегазоносности рифей-вендских отложений малоизученных районов, таких как северо-восточные районы Волго-Уральской нефтегазоносной провинции. Представлена малоизученных районов, таких как северо-восточные районы Волго-Уральской нефтегазоносной провйции. Представлена хасти Волго-Уральской нефтегазоносной провинции. Особое внимание акцентируется на бассейновом моделировании части Волго-Уральской нефтегазоносной провинции. Особое внимание акцентируется на бассейновом моделировании процессов нефтегазообразования. В ходе проведения исследований выполнено моделирование разрезов трех скважин, вскрывших верхнепротерозойские породы на северо-востоке Пермского края и Республики Коми: Кельтменская-1, Красновишерская-18, Боровицкая-624. Приведены методические особенности используемых программных комплексов, этапность исследования, включающая сбор и ввод исходных данных, обработка параметров, вычисление и калибровка . рифейских и вендских отложений данной территории, обусловлены недостаточным объемом информации по строению и составу отложений, неполным вскрытием древних отложений в скважинах и противоречивостью геофизических данных. Кроме того, сложность реконструкции заключается в недостатке сведений о геотермических условия разрезов, многочисленных перерывах в осадконакоплении и размывах отложений. По результатам моделирования большая часть рифейско-вендского осадочного разреза находится в главной зоне нефтеобразования. Проведенные исследования позволили авторам сделать вывод о повышенных перспективах обнаружения нефтяных углеводородов в широком диапазоне глубин в районах бурения скважин Красновишерская-18 и Боровицкая-624. Перспективы обнаружения в разрезе газообразных углеводородов сушественно более низкие Проведенные исспедования и полученные результаты ставят проблему развития геолого-разведочных работ в малоизученных районах северо-востока Волго-Уральской нефтегазоносной провинции, прежде всего опорно-параметрического бурения в комплексе с зонально-региональными геофизическими исследованиями.

Svetlana E. Bashkova (Author ID in Scopus: 37561140000) - PhD in Geology and Mineralogy, Scientific Secretary, Head of the Sector of Scientific Support of Parametric and Ultra-Deep Drilling (tel: + 0079519367460 , e-mail: sbashkova 9 in Geology

Tatyana V. Karaseva (Author ID in Scopus: 37111172100) - Doctor of Geology and Mineralogy, Professor, Director of Innovative Technologies (tel.: +007 342244 13 14, email: kamniikigs@rusgeology.ru).

Inna A. Kozlova (Author ID in Scopus: 37561646700 ) - PhD in Geology and Mineralogy, Associate Professor, Deputy Head of the Department (tel.: +007 342 219 83 67, email: ikozlova@pstu.ru). The contact person for correspondence.

Andrey N. Bashkov - PhD in Geology and Mineralogy, Chief Geologist (tel.: +007912 88294 91, e-mail: bashkov41@yandex.ru).

Башкова Светлана Евгеньевна - кандидат геолого-минералогических наук, ученый секретарь, заведующий сектором научного сопровождения параметрического и сверхглубокого бурения (тел.: +007951936 74 60, e-mail: sbashkova@mail.ru)

Карасева Татьяна Владимировна - доктор геолого-минералогических наук, профессор, директор по инновационным технологиям (тел.: +007 3422441314 , e-mail: kamniikigs@rusgeology.ru).

Козлова Инна Анатольевна - кандидат геолого-минералогических наук, доцент, заместитель заведующего кафедрой (тел.: +007 3422198367 , е-таil: ikozlova@pstu.ru). Контактное лицо для переписки.

Башков Андрей Николаевич - кандидат геолого-минералогических наук, главный геолог (тел.: +007 912 882 94 91, e-mail: bashkov41@yandex.ru). 


\section{Introduction}

The problem of assessment of oil and gas potential of the Riphean and Vendian deposits in the northern part of the Volga-Ural oil and gas province (OGP) still remains unsolved. It is caused by insufficient degree of exploration of deposits by drilling [1-12], as well as by inadequate attention paid to advanced methods applied to assess the potential. Such methods include basin modeling of formation of potentially prospective oil and gas plays and modeling of oil and gas formation and accumulation processes; these methods are especially efficient in case of poorly explored regions and deposits on which just a little information is available [13-18]. Abroad, where a big emphasis is placed on studying the behaviour and trends of oil systems' evolution through exploration of big oil and gas basins in different countries, significant attention is paid to the development of basin modeling as one of the most efficient methods of scientifically substantiated prediction of oil and gas occurrence [19-39].

\section{Brief lithologic and stratigraphic characteristic}

The Riphean and Vendian deposits in the northeast of the Volga-Ural OGP are characterized by extremely low degree of exploration by geophysical methods and drilling. In the northeastern part of the Volga-Ural only the Upper Riphean deposits from among the Riphean plays are developed. Based on geophysical data, the thickness of the Riphean deposits exceeds 2,000 m. The Late Riphean deposits crop up in cores of anticline structures of the PolyudovskoKolchimsky anticlinorium within the following four suites (from bottom to top): Rassolninskaya, Deminskaya, Nizvenskaya, and UstChurochinskaya. The Rassolninskaya suite consists of field spar and quartz sand stone, argillite, and silt-rich mudstone, as well as of silt stone with occasional interlayers of dolomite with tuff interlayers in the upper part. The boundary with underlying deposits is not clear. The suite thickness is $800-1,000 \mathrm{~m}$. The Deminskaya suite consists of dolomitic limestone with dolomite interlayers and clayey limestone, marl, and argillite. Stromatolite is present. The suite thickness is $300-400 \mathrm{~m}$. The Nizvenskaya suite mainly consists of grey dolomites with residues of stromatolite and microphytolite, as well as of alternation of layers of argillite, silt stone, and clayey limestone. The total suite thickness reaches 1,500-1,600 m. The Ust-Churochinskaya suite was uncovered by Well 517 of the Ostyak profile in $1,173-1,490 \mathrm{~m}$ interval and it is represented by small- and medium-grained sand stone and darkgrey argillite. The Ust-Churochinskaya suite, distinguished as the lower part of the Vendian based on the results of geological mapping in the northern sections of the Volga-Ural, is considered by some specialists (Yu.A. Yekhlakov, B.P. Bogdanov) to be a part of the Upper Riphean, thus terminating that cycle of sedimentation, in virtue of conformable bedding with the Nizvenskaya suite and lithologic and facie particulars of the section. Rocks of the abovementioned suites underlay the Timanian horizon of the Middle Devonian.

In the north of the explored territory of the Komi Republic, Keltmenskaya-1 well has uncovered a section of the Upper Riphean deposits represented by the Yshkimesskaya and Vapolskaya suites which are similar to the Deminskaya and Nizvenskaya suites respectively. Tectonically the well is located on the Keltmensky swell; the swell makes the Vychegodsky (Pre-Timanian) downwarping more complex. The Vapolskaya suite thickness, fully uncovered, is $1,031 \mathrm{~m}$. The Yshkimesskaya suite section has not been uncovered in full; the thickness of its uncovered part is (to the depth of $4900 \mathrm{~m}$ ) is $959 \mathrm{~m}$.

The Low Vendian deposits in the Vychegodsky (Pre-Timanian) down-warping have been uncovered by Keltmenskaya -1 well at the depth of $2,310 \mathrm{~m}$ and their thickness is $600 \mathrm{~m}$. The deposits are represented by the Vychegodskaya suite and they non-conformably overlay the Vapolskaya suite deposit thickness of the Late Riphean. The Vychegodskaya suite in its lower stratum is mostly silty and in the upper part it is represented by sand stone interlaid by silt stone and argillite. In the fold-and-thrust area of the Western Urals in the Polyudovsky zone the deposits of the Lower Vendian period have been determined within the Churochinskaya (argillite and sand stratum) and Ilya-Volga (silt stone stratum) suites.

The Upper Vendian deposits in the northeast of the explored territory are singled out within the Redkinsky and Kotlinsky horizons corresponding to the Borodulin and Kudymkar series. In the PreTimanian, the Redkinsky horizon is represented by the Ust-Pinezhskaya suite, the full section of which has been uncovered by Keltmenskaya -1 well. The $432 \mathrm{~m}$ suite consists of alternating layers of 
argillite and silt stone of grey and greenish-grey color; they are dense and locally fragile. The UstPinezhskaya suite's deposits are conformably interlaid by rocks of the Kotlinsky horizon represented within the Krasavinskaya and Mezensko-Padunskaya suites. $152 \mathrm{~m}$ thick Krasavinskaya argillite suite consists of dark-grey dense argillite with rear interlayers of silt stone and clayey silt stone. This suite is conformably overlaid by Mezenskaya suite rocks represented by irregular interlaying of silt stone and argillite. These deposits are interlaid by a terrigenous stratum of the Timanian horizon of the Middle Devon.

\section{Procedure}

To build 1D models the PetroMod [40-42] software product and the author's reconstructions were applied to reconstruct the process of deposit down-warping, sedimentation, and evolution of paleothermal conditions of rocks within the sedimentary mantle and, based on the conducted research, develop oil and gas formation models. The overall simulation scheme consists of several main stages: collect and input initial data, process parameters, calculate and calibrate models. At the first stage, data on the structure and evolution of a territory in question are entered. Mandatory parameters include the following: geological age of deposits, depth of the surface of rocks of various stratigraphic series, geological time of sedimentation, erosion, and non-depositional hiatus, as well as lithological composition of reservoirs, etc. In the PetroMod software, the timeframes specific to age are taken based on the general stratigraphic scale of A.P. Karpinsky Russian Geological Research Institute (1995). The lithological composition is limited by the following groups: clay, argillite, silt stone, sand and sand stone, carbonate (limestone, dolomite, and marl), evaporite (salt, gypsum, anhydrite), carbon, basement rocks (granite, touchstone, andesite). In addition, petrophysical and geochemical rock characteristics determining the reservoir and oil-and-gas source properties are included. Most parameters are included based on drilling results and geophysical data. If any new information is received, the initial database can be topped up at any stage. The more initial parameters based on drilling results we have, the more exact and reliable simulation results we obtain. The outcome of the first stage is the deposit formation model. At the second stage, boundary geological conditions are set for the model including the following: paleodepth of water, sedimentation water temperature, heat flow, etc. The third stage reproduces the process of down-warping, thermal evolution, maturing of organic substance, change of petrophysical parameters of rocks, and actual parameters. Porosity and pressures (lithostatic pressure, hydrostatic pressure, and pore pressure), vitrinite reflectance, temperature dependences, and other parameters are calculated automatically. Models are calibrated based on actual data (modern temperature, vitrinite reflectance and, in some cases, rock porosity, etc.). At the moment of calibration it is important to take into account different scenarios of changes in the basement depth based on geophysical information, special aspects of erosion events, influence of regional and local geothermal processes in each region which can have significant impact on the fairness of developed models.

The specific feature of simulation for the Riphean and Vendian potential oil and gas play is insufficient amount of information about the structure and composition of deposits, which is often caused by incomplete uncovering of ancient deposits in wells and by inconsistency of geophysical data. Moreover, the complexity of reconstruction is caused by the lack of data on geothermal conditions of sections, multiple nondepositional hiatuses, and washing away of deposits. 1D simulation has been done for profiles of Keltmenskaya-1 well, Krasnovisherskaya-18 well, and Borovitskaya-624 well (Fig. 1).

\section{Results}

The simulation of the profile of Keltmenskaya1 well drilled in the southeast of the Vychegodsky down-warping in the zone of conjunction with the Komi-Permyak dome fold, in the area scarcely explored by drilling, is based mainly on indirect data and materials from adjacent territories due to limited data on modern temperatures and vitrinite reflectance. Under the terrigenous stratum of the Upper Devon the well has uncovered the Vendian and Riphean deposits in considerable amount. The Riphean deposits within the section are represented by grey carbonate stratum as follows: limestone, dolomite (more or less clayey), and sometimes marl. In the upper part separate samples of rocks with increased source rock properties have been found. The Vendian play consists mainly of terrigenous rocks; oil and gas source rock has not 

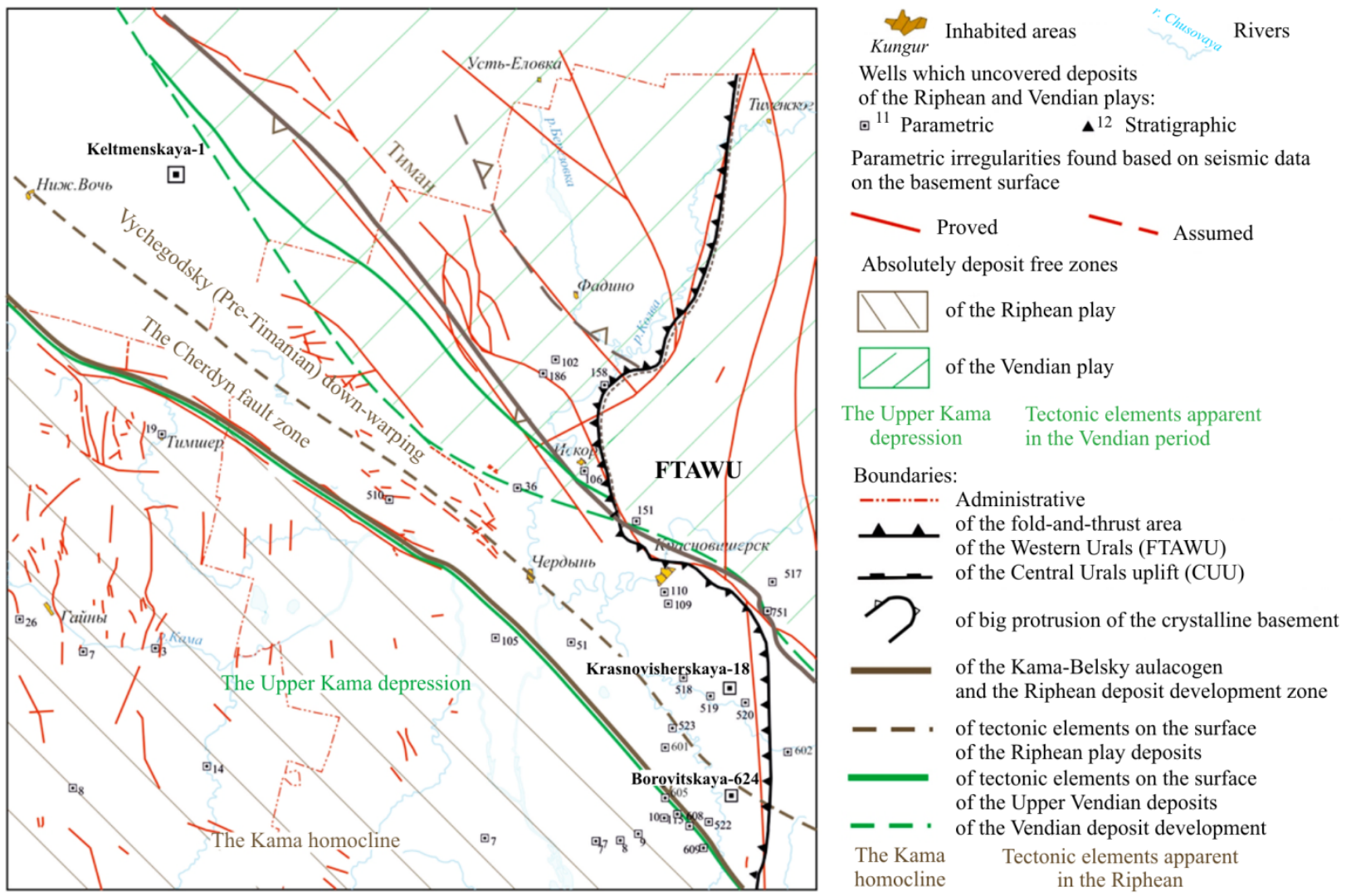

Fig. 1. Fragment of the tectonic zoning scheme of the Riphean and Vendian deposits in the northeast of the Volga-Ural OGP

been found. During the simulation the dependences of modern values of rock temperature and porosity, as well as vitrinite reflectance from the depth (Fig. 2) were reconstructed.

The gradient of temperature over the profile in general does not exceed $2{ }^{\circ} \mathrm{C}$. The petrophysical model of porosity in general corresponds to rock compaction principle; in the Vendian play it is about $12-13 \%$, in the Riphean play is goes down to $7 \%$ and less. Compared to the Paleozoic deposits, in the Vendian and Riphean plays there is an increased gradient of vitrinite reflectance change. Based on the simulation results two main stages of down-warping of deposits were singled out as follows: the Riphean and Vendian, which, later on, were supplemented by less intensive Devonian-Permian stage (Fig. 3).

Throughout the Riphean-and-Vendian time a big amount of sediments was accumulated reaching more than $6 \mathrm{~km}$. The first stages of down-warping were characterized by sedimentation accumulation rate ranging from 7 to $19 \mathrm{~m} /$ million years, whereas during the Vendian time the down-warping rate was
$18.5 \mathrm{~m} / \mathrm{million}$ years. Towards the end of the Vendian stage, the basement surface temperature reached $153{ }^{\circ} \mathrm{C}$ already. Based on geophysical data, the modern basement depth is $6,100 \mathrm{~m}$ at the temperature of $124{ }^{\circ} \mathrm{C}$ based on the reconstruction data. As a result, the bottom of the Upper Riphean deposit already entered the Main Oil Formation Zone (MOFZ) during the Late Riphean time, whereas the Riphean top entered the MOFZ during the Vendian time. The Lower Vendian deposits got into the MOFZ at the end of the Vendian time, whereas the lower part of the Upper Vendian deposits got into the MOFZ in the Devonian time. Based on the simulation results, the overlying Upper Vendian and Paleozoic deposits did not enter the MOFZ. Maybe this is the only case for the Volga-Ural and TimanoPechora provinces when the Proterozoic plays did not enter the MOFZ in full. It should be mentioned that in general the geological and paleothermal situation obtained correspond to the results of reconstructions done by other authors [19]. At the Mesozoic-and-Cenozoic stage sedimentation almost terminated. 
So, the lower part of the Upper Riphean and Middle Riphean deposits passed all stages of oil formation and entered the Main Gas Formation Zone (MGFZ) beginning with the Early Paleozoic time. The modern location of the MOFZ is registered in the Riphean-Vendian deposits at the interval of 1,760-4,990 $\mathrm{m}\left(\mathrm{MK}_{1}\right.$ $\mathrm{MK}_{3}$ ); below that level the deposits could enter the MGFZ. The deep boundary of oil quality (oil deadline) is $5150 \mathrm{~m}$.
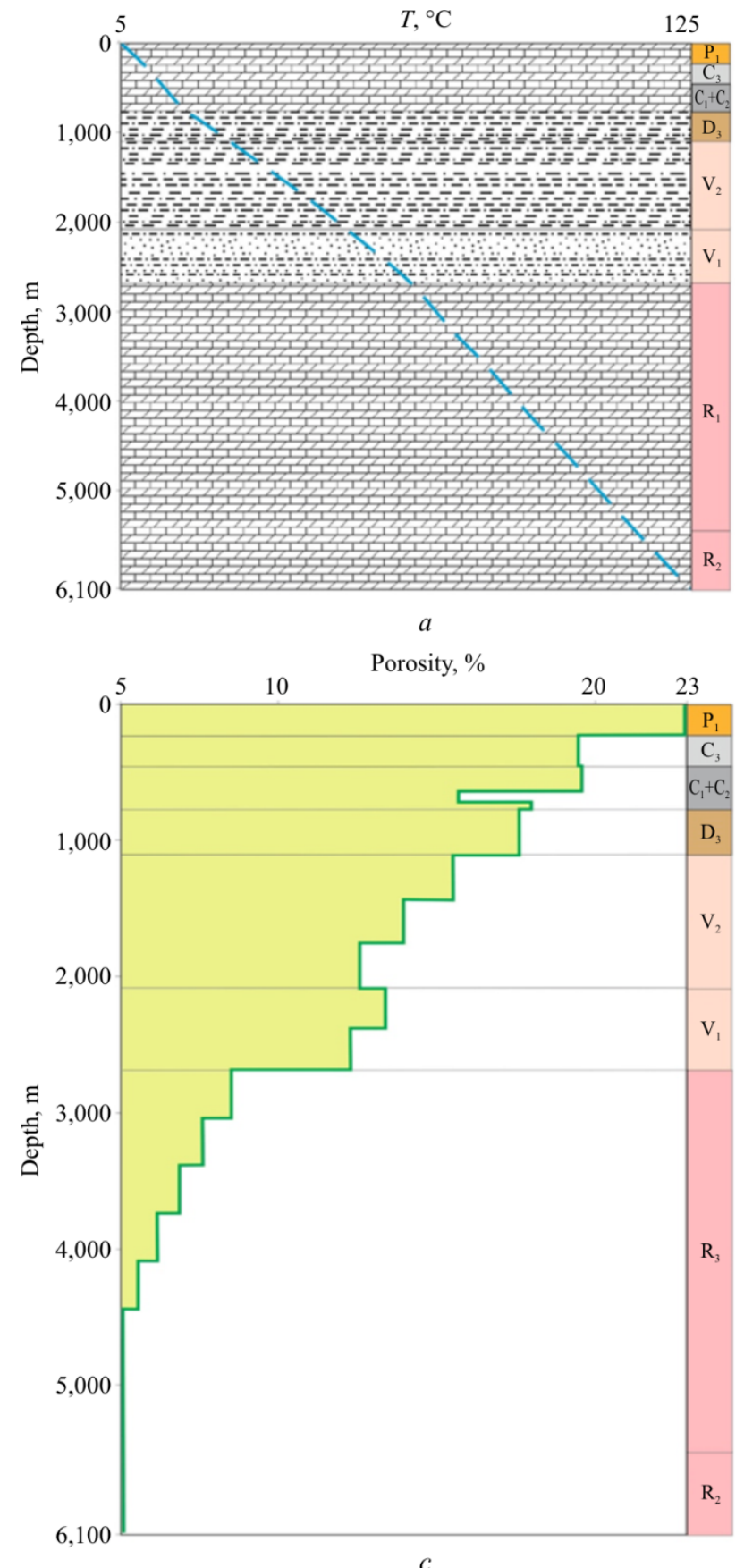

Krasnovisherskaya-18 well is located in the northeastern part of the exploration work zone where in the bottom-hole area only the Vendian deposits have been uncovered. According to geophysical data, with the basement depth of 5.6 $\mathrm{km}$ under the Vendian deposits there are the Upper Riphean rocks. In Fig. 4 there are the models of changes in modern temperature, vitrinite reflectance, and porosity over the well profile. In general, the data obtained are
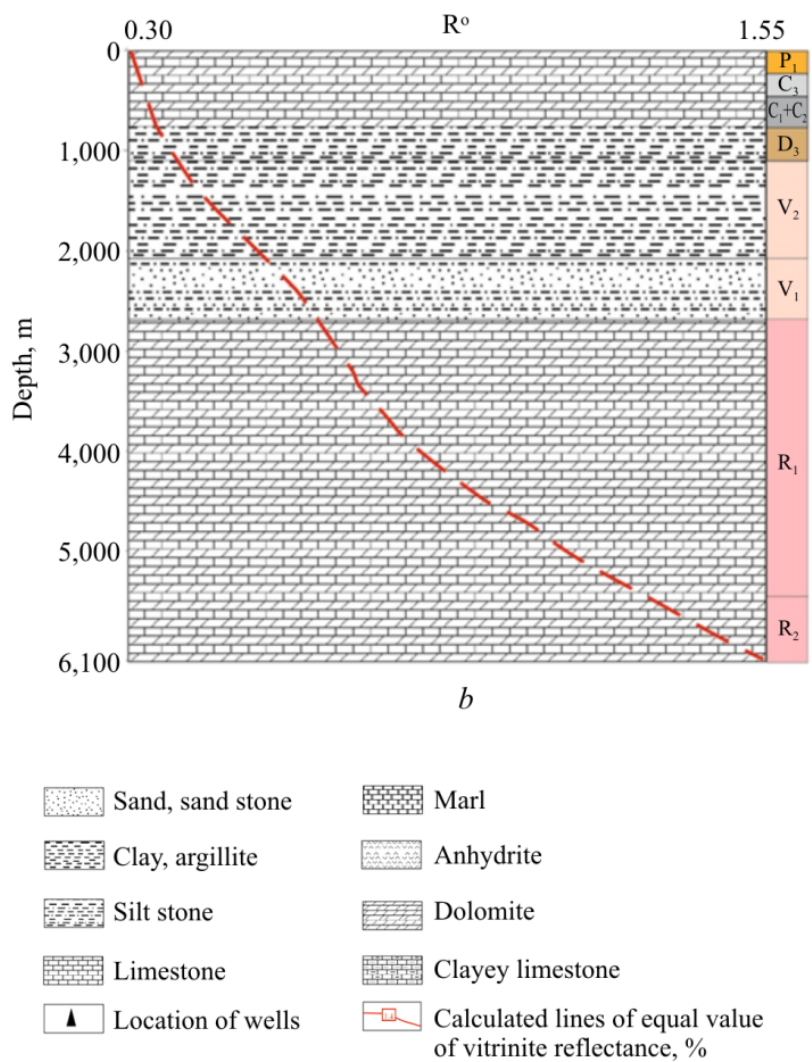

\section{Well profile models}

$\longrightarrow$ Modern temperature change line, $\mathrm{C}^{\circ}$

- Vitrinite reflectance change line, $\mathrm{R}^{\circ}$

$\square$ Porosity change line

- Actual measurement of porosity $(\%)$ and temperature $\left({ }^{\circ} \mathrm{C}\right)$

Models of changes in paleotemperature and oil formation zoning Epeirogenic curves

Paleotemperature change line, $\mathrm{C}^{\circ}$

Vitrinite reflectance change line, $\mathrm{R}^{\circ}$

Rocks with immature organic substance

Main oil formation zone

Main gas formation zone

Basement down-warping line

Fluid migration direction from the oil integration zone

Fluid surface seepage at the hypergenesis stage

Fig. 2. Models of change in modern temperature $(a)$, vitrinite reflectance $(b)$, and porosity $(c)$ in the area of Keltmenskaya-1 well 

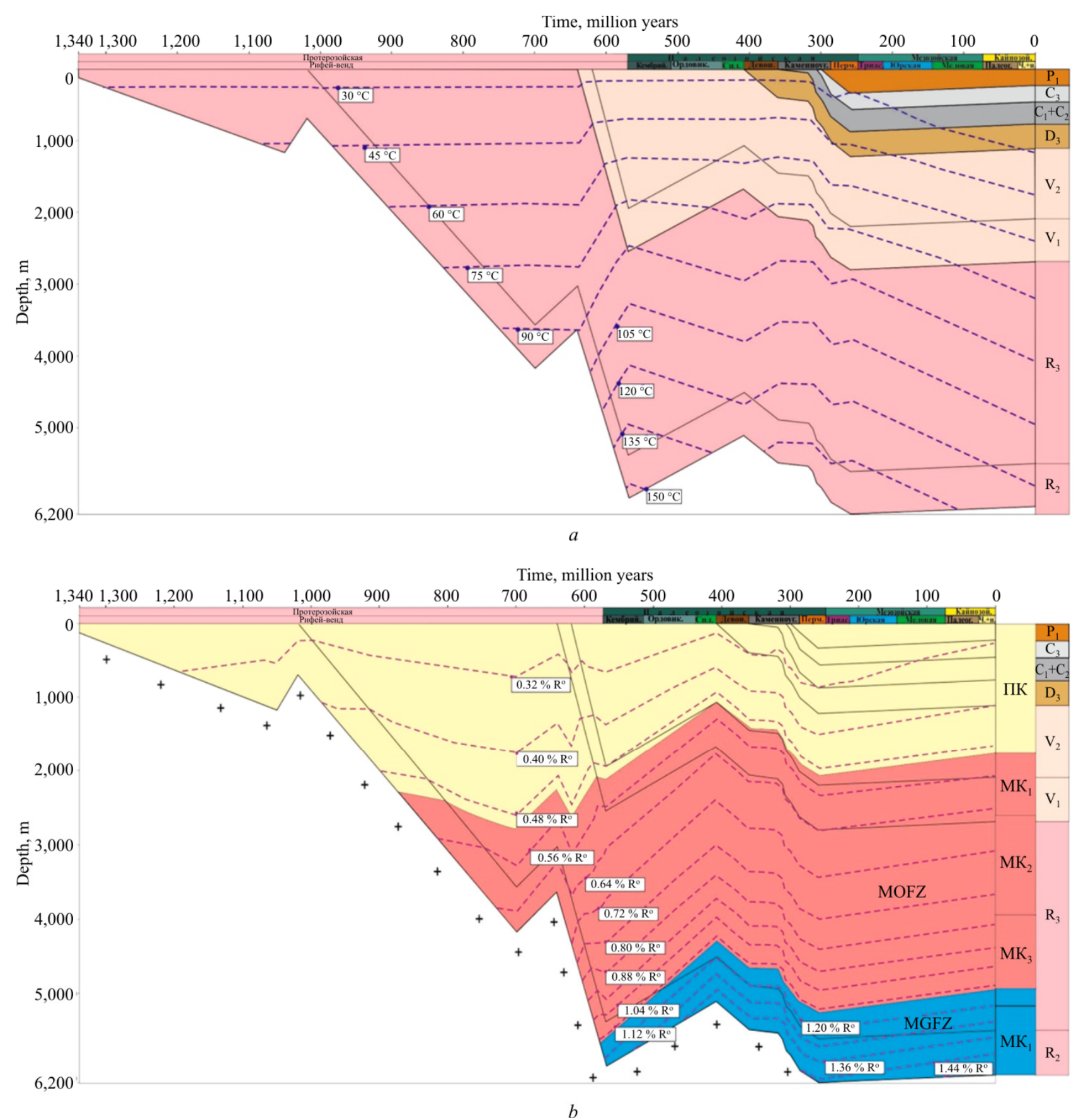

Fig. 3. Models of changes in paleotemperature ( $a$ ) and oil and gas formation zoning $(b)$ in the area of Keltmenskaya-1 well. Please see the legend in Fig. 2

similar to the results of well surveys in the drilling area. At the same time, the actual data on these parameters for Krasnovisherskaya-18 well are missing and this decreases the fairness of the obtained results.

The reconstructed gradient of change in modern temperatures slightly exceeds $2 \% 100 \mathrm{~m}$. The vitrinite reflectance in the sedimentary mantle basal part reaches $1.41 \%$. Two main stages of down-warping and sedimentation are singled out
(Fig. 5). At the Riphean-Vendian stage the average sedimentation rate exceeded $6.5 \mathrm{~m} /$ million years. The deposit thickness reached 4,250 m. The temperature at the top of the basement reached $120{ }^{\circ} \mathrm{C}$ by the end of the first stage. At the beginning of the Middle Devonian, as a result of significant uplift of the territory, the previously accumulated $1,000 \mathrm{~m}$ thick deposits were destroyed. In the Devonian-Permian time, the second stage of intensive down-warping took place. The down- 
warping was very quick; the rate exceeded $20 \mathrm{~m} /$ million years. By the end of the second stage of the down-warping, the basement temperature exceeded $145{ }^{\circ} \mathrm{C}$. The Vendian play of insignificant thickness entered the MOFZ in the Permian time only, whereas the significant lower part of the Riphean play did that already in the Late Riphean and, in the Triassic time, it left the MOFZ and entered the MGFZ (please see Fig. 5). In the Permian time, the Devonian and Lower Carboniferous deposits entered the MOFZ, and, in the Cenozoic time, the lower part of the Middle Carboniferous deposits entered the MOFZ. As a result, based on preliminary information, in the territory of Krasnovisherskaya-18 well, today a connate MOFZ is located within an interval of 1,830-4,930 $\mathrm{m}\left(\mathrm{MK}_{1}-\mathrm{MK}_{3}\right)$, i.e. the deposit plays in question entered the MOFZ completely, and, in
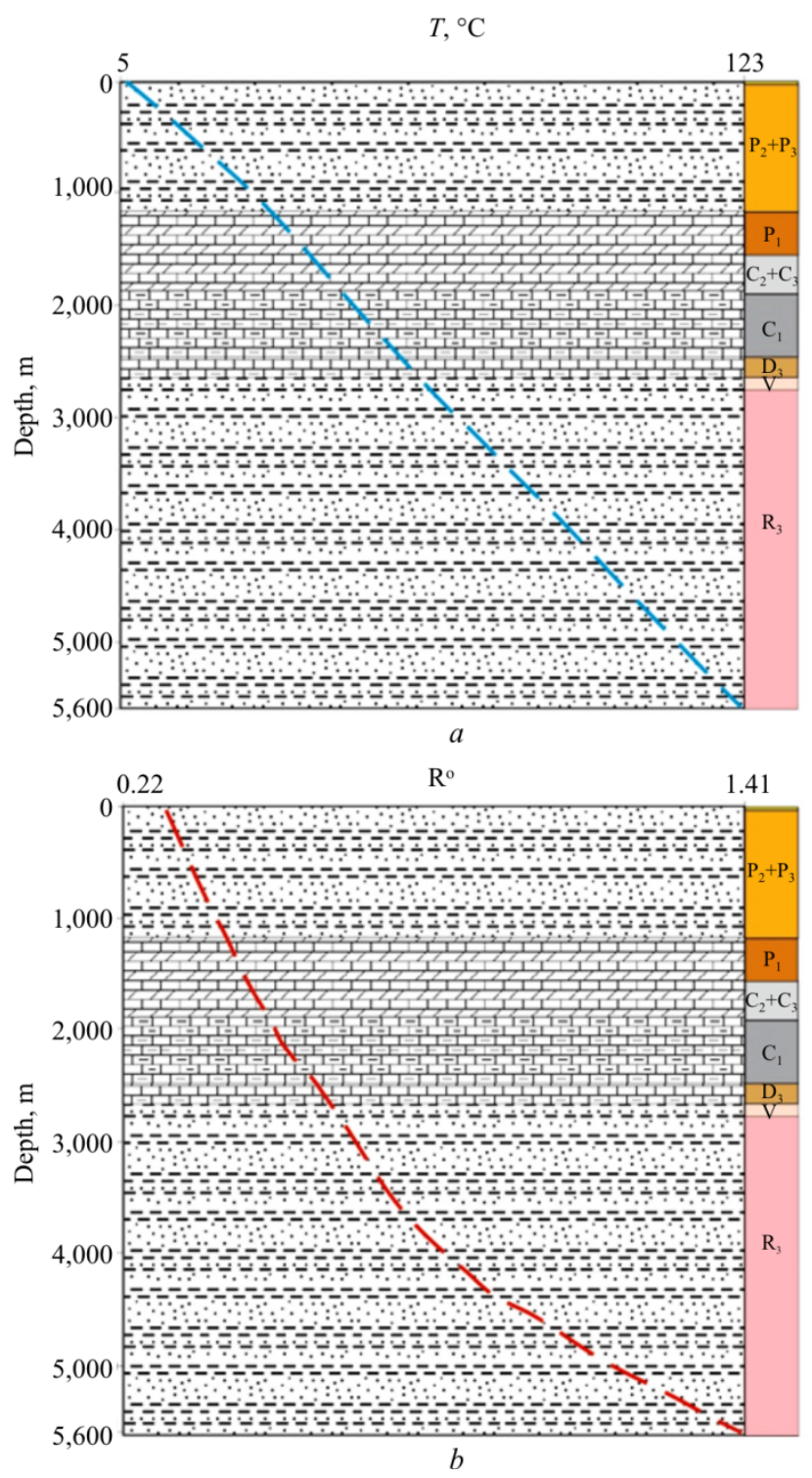

basal strata, they could enter the MGFZ as well. The deep boundary of oil quality is $5,240 \mathrm{M}$.

To the south of Krasnovishersk area there are wells of the Borovitsky profile. Simulation was done for the area of Borovitskaya-624 well which had uncovered deposits of the Upper Vendian of the Borodulinskaya series at the depth of $2,878 \mathrm{~m}$. In the upper part the Vendian rocks are represented by thin-layer dark-brown silt stones; in the lower part there are thin-layer, indistinctly laminated, dense greenish-grey argillites. Based on geophysical data, the sedimentary mantle is represented by the Vendian and Riphean deposits in the lower part of the profile. In Fig. 6 there are models of calculated and actual values of modern temperatures, vitrinite reflectance, and porosity. The temperature measured in the well at 2,080 and 2,341 m was equal to $32{ }^{\circ} \mathrm{C}$, which is slightly lower

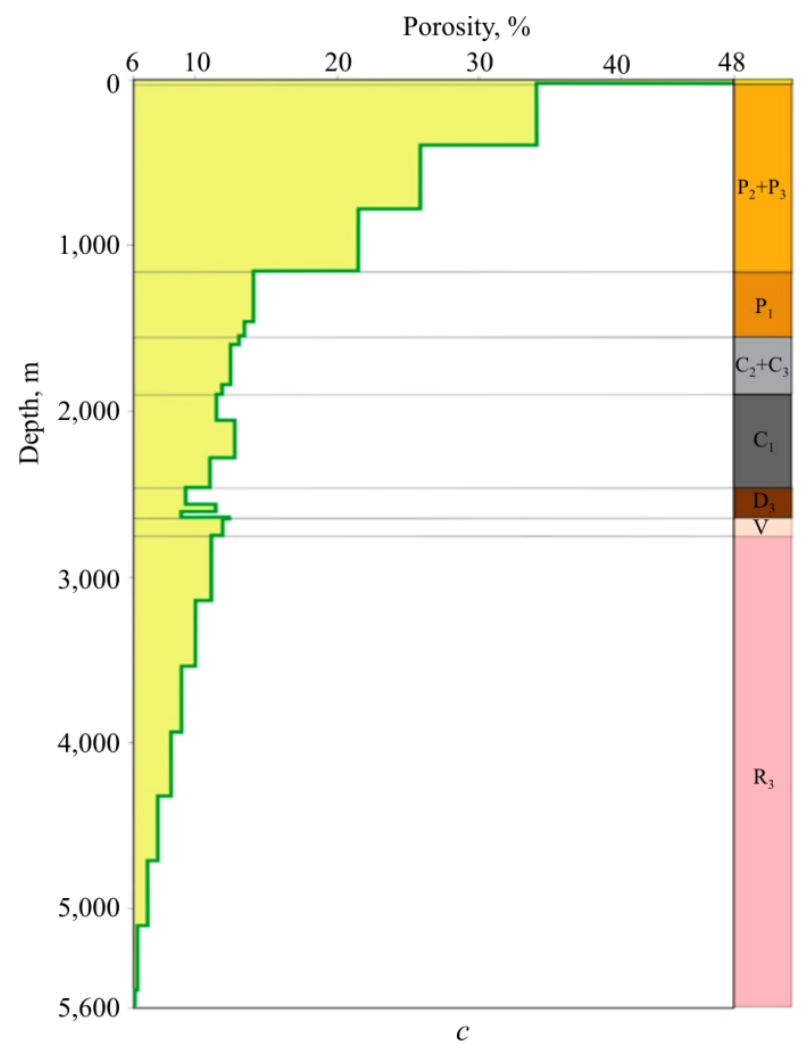

Fig. 4. Models of change in modern temperature $(a)$, vitrinite reflectance $(\sigma)$, and porosity $(b)$ in the area of Krasnovisherskaya-18 well. Please see the legend in Fig. 2 


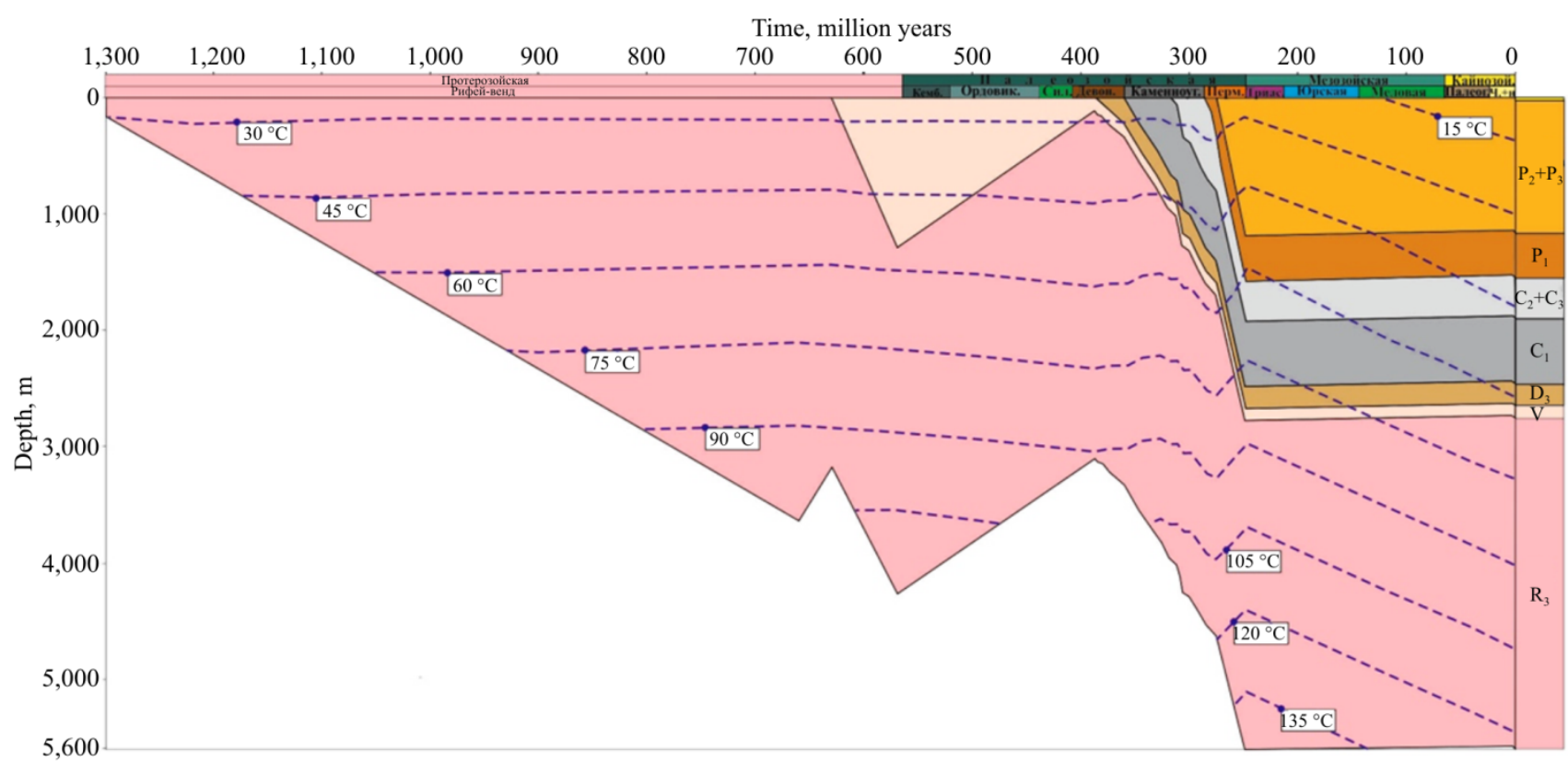

$a$

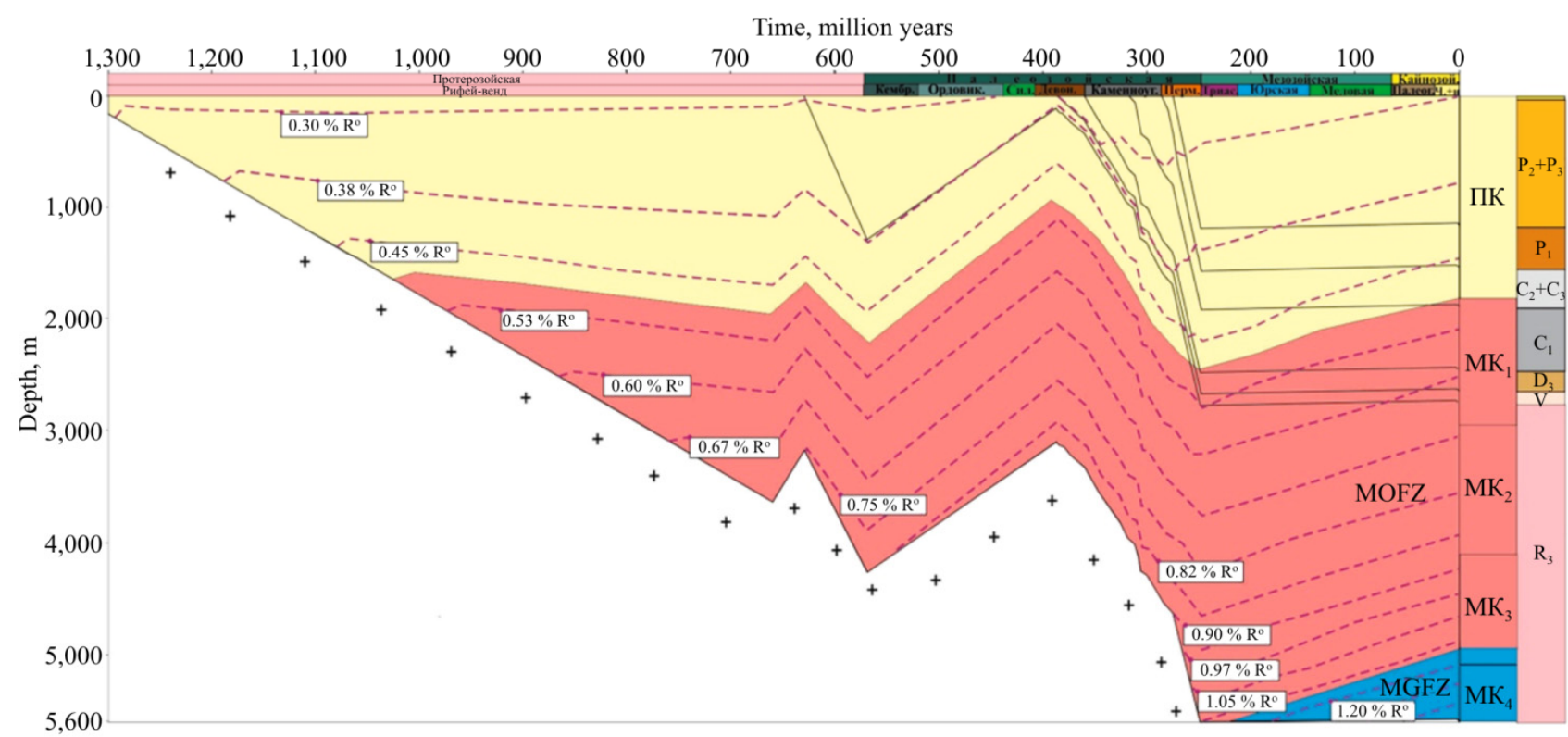

$b$

Fig. 5. Models of change in paleotemperature $(a)$ and oil and gas formation zoning $(b)$ in the area of Krasnovisherskaya-18 well. Please see the legend in Fig. 2

compared to the wells of the drilling territory. Maybe it was caused by the quality of the survey work done. The temperature increases with the depth on the calculated curve, as well as in the zone of measurements. At the abovementioned depths the temperature values are 44 and $51{ }^{\circ} \mathrm{C}$ respectively. The actual porosity of the Serpukhovian deposits is $11 \%$, whereas on the model this value is $12 \%$, which shows that the calibration was acceptable. The petrophysical model characterizes low porosity of the Vendian and Riphean deposits; only in the upper part it exceeds $10 \%$. No vitrinite reflectance studies have been performed. On the down-warping model (Fig. 7) there are two main down-warping stages: the Riphean-Vendian and DevonianPermian. The first stage is characterized by a high rate of sedimentation: over $50 \mathrm{~m} / \mathrm{million}$ 
years. Over the entire period the deposits of more than 4,100 m thick were accumulated. The Vendian bottom temperature was $113{ }^{\circ} \mathrm{C}$. The Devonian-Permian time is characterized by down-warping accompanied by a sedimentation rate exceeding $24 \mathrm{~m} /$ million years. By the end of the second stage, the basement depth was $5.7 \mathrm{~km}$ and the temperature increased up to $142{ }^{\circ} \mathrm{C}$. In the Mesozoic-Cenozoic time, sedimentation almost terminated. Based on geophysical data, the modern depth of the basement is $5.6 \mathrm{~km}$ at a temperature of $120{ }^{\circ} \mathrm{C}$ reconstructed in the model. During the Vendian time, the bottom of
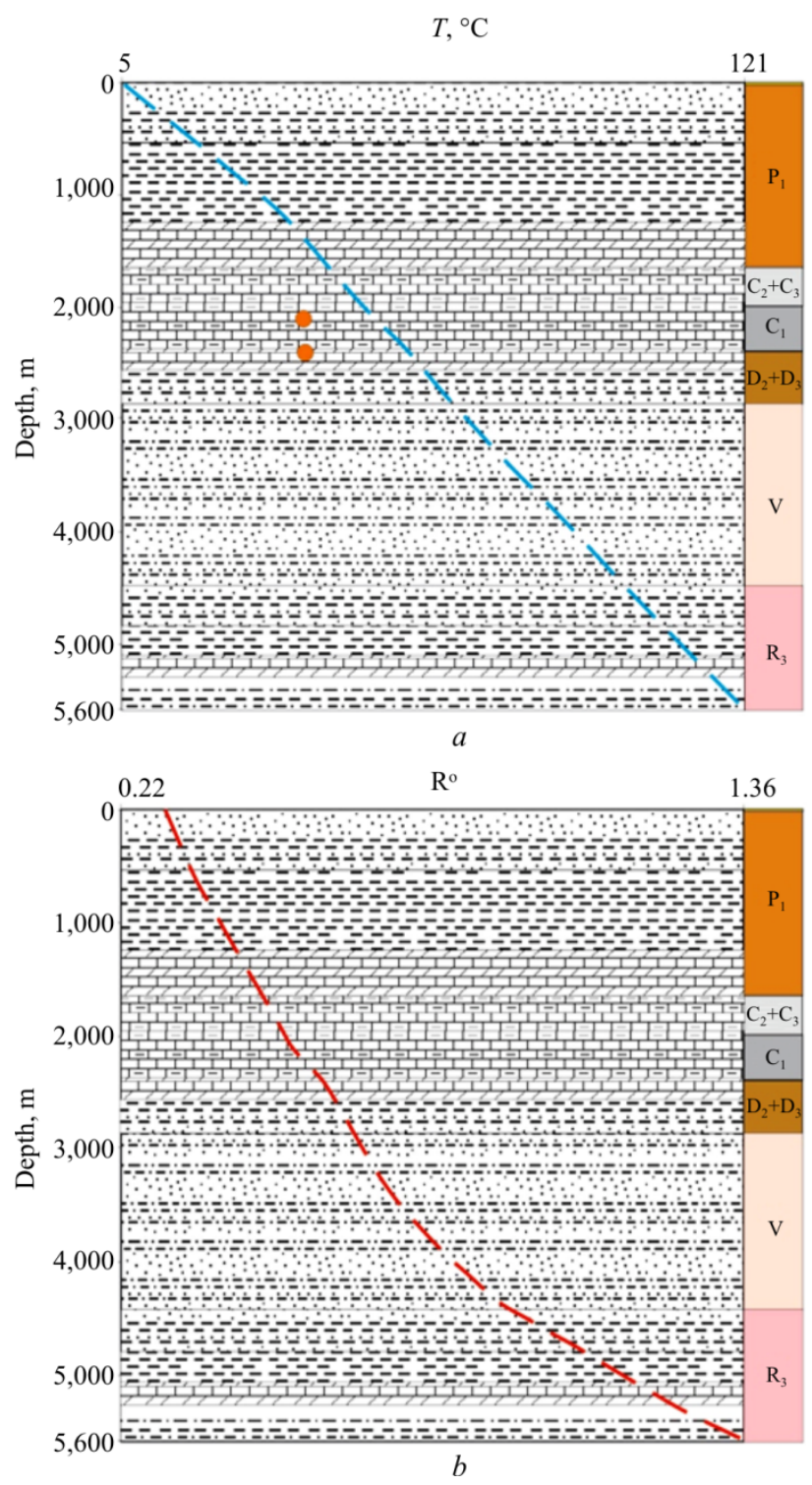

the Riphean-Vendian play entered the MOFZ and, at the beginning of the Cretaceous period, it left it entering the MGFZ. In the zone adjacent to the uppermost zone, the Vendian deposits entered the MOFZ in the Permian time only and they remained at the initial stage of the MOFZ $\left(\mathrm{MK}_{1}\right)$. The simulation done shows that in the territory of Borovitskaya-624 well the MOFZ corresponds to the depth of 1,820-5,050 m $\left(\mathrm{MK}_{1}-\mathrm{MK}_{3}\right)$. The Riphean play was partly in the MOFZ and MGFZ, whereas the Vendian play was only in the MOFZ. The deep boundary of oil quality corresponds to $5,150 \mathrm{~m}$.

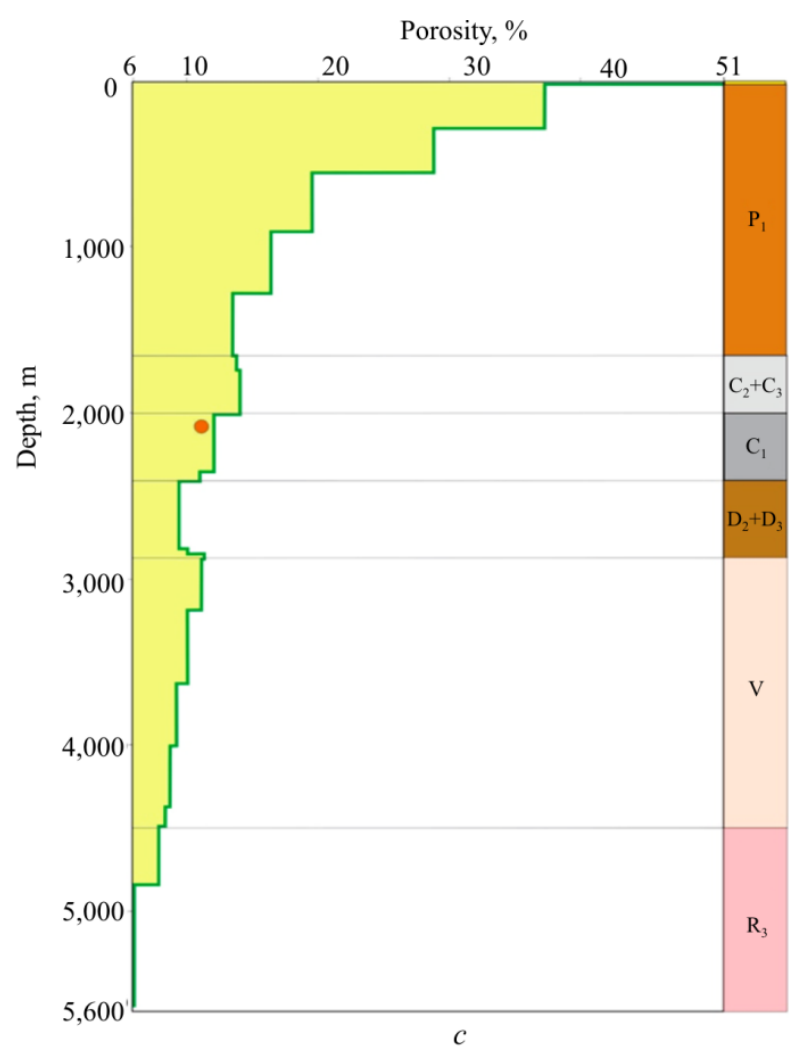

Fig. 6. Models of change in modern temperature $(a)$, vitrinite reflectance $(b)$, and porosity $(c)$ in the area of Well 624 of the Borovitsky profile.

Please see the legend in Fig. 2 

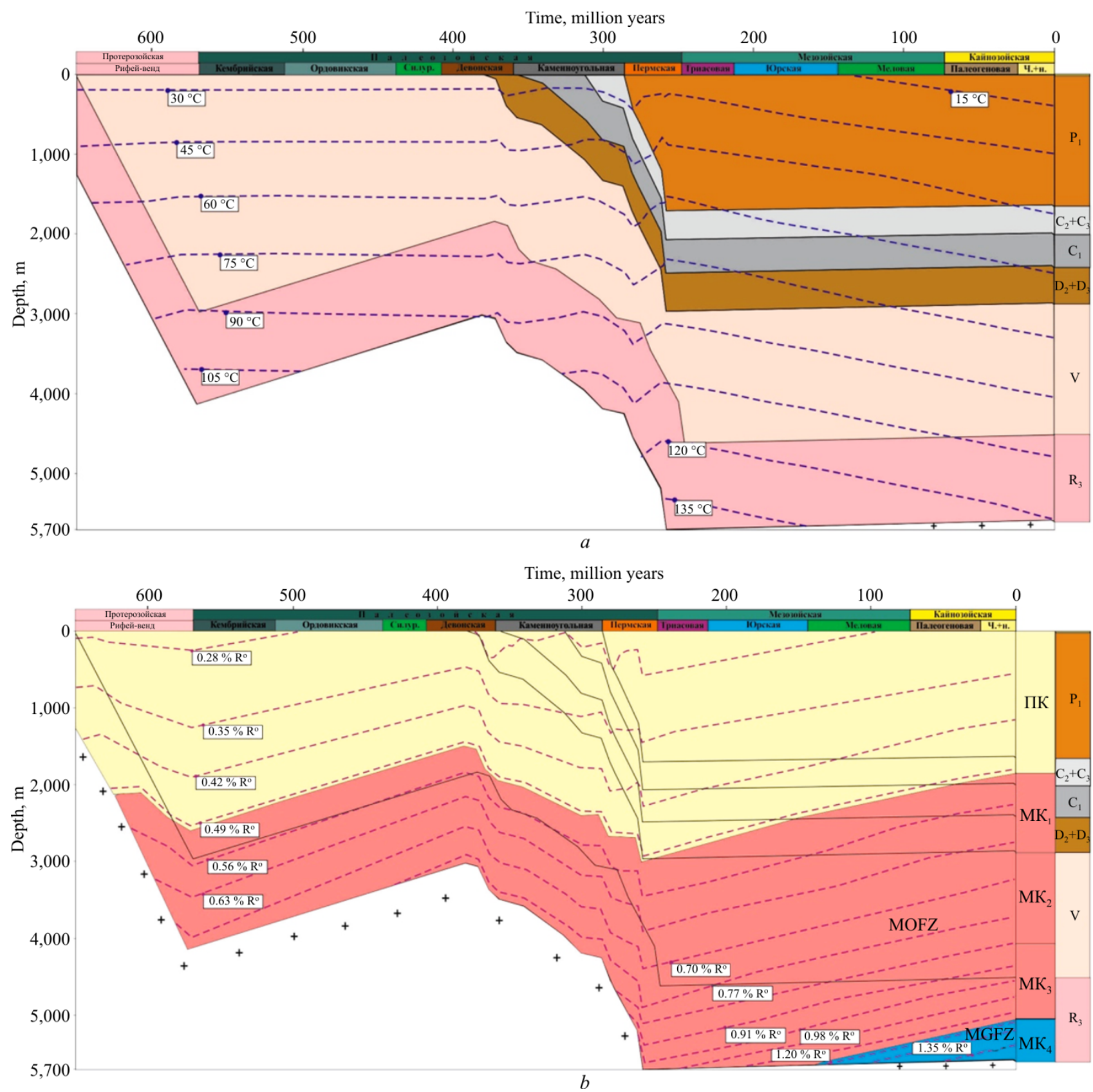

Fig. 7. Models of change in paleotemperature $(a)$ and oil and gas formation zoning $(b)$ in the area of Well 624 of the Borovitsky profile. Please see the legend in Fig. 2

\section{Conclusion}

So, despite limited initial data, the results of 1D simulation of processes of the Riphean and Vendian deposit formation allowed us to come to a number of important conclusions to be able to evaluate hydrocarbon potential of insufficiently explored territories of the northeast of the VolgaUral OGP:

- in the explored territories of drilling the Riphean-Vendian stage of down-warping played a leading role in the sedimentary mantle generation; at the same time, the sedimentation rates varied within a wide range (up to $50 \mathrm{~m} /$ million years) and were favorable to generation of oil-and-gas source rocks;

- the connate top wall of the MOFZ in the studied profiles is located at the depth of 1,760$1,830 \mathrm{~m}$, whereas the bottom is located at the depth of 4,930-5,050 m, which is significantly lower than in the western territories of the northern Volga-Ural and that is indicative of a possibility of wider spreading of petroleum deposits over the depth; 
- the Riphean deposits, as well as the Vendian deposits entered the MOFZ, however, the geological time of entering and the degree of catagenetic transformation of organic substance differ significantly; the Vendian deposits entered the initial stage of MOFZ $\left(\mathrm{MK}_{1}\right)$ in the Paleozoic time; Keltmenskaya -1 well territory, where the upper part of this play did not even enter the MOFZ, is an exception; the development of the MGFZ was revealed only at the depths exceeding 4,930 $\mathrm{m}$ in the lower part of the Riphean deposits;

- in general, the data obtained are indicative of higher prospects of drilling territories of
Krasnovisherskaya-18 and Borovitskaya-624 wells in terms of oil encountering and are indicative of lower prospects of gas encountering in all territories in question;

- the results of the survey define a problem of development of geological prospecting work in poorly explored territories in the northeastern Volga-Ural OGP; first of all, it concerns stratigraphic and parametric drilling with detailed geochemical study of rocks of the Riphean-Vendian age in conjunction with zonal-and-regional geological-and-geophysical surveys.

\section{References}

1. Balashova M.M., Koblova A.Z., Provorov V.M. O pozdnekembriyskom neftegazoobrazovanii na severe Uralo-Povolzhya [On the Late Cambrian oil and gas formation in the north of the Ural-Volga region]. Oil and Gas Geology, 1982, no.9, pp.40-43.

2. Bashkova S.E., Belokon A.V. Novye podkhody k poiskam uglevodorodov $\mathrm{v}$ rifeyskikh otlozheniyakh vostoka Russkoy platformy [New approaches to the search for hydrocarbons in the Riphean deposits of the east of the Russian platform]. Degazatsiya Zemli: geoflyuidy, neft i gaz, paragenezy $v$ sisteme goryuchikh iskopaemykh. Tezisy mezhdunarodnoy konferentsii. Moscow, GEOS, 2006, pp.46-49.

3. Bashkova S.E., Karaseva T.V., Popov S.G. et al. Geologo-geokhimicheskie aspekty prognoza neftegazonosnosti rifey-vendskikh otlozheniy Volgo-Uralskoy neftegazonosnoy provintsii [Geological and geochemical aspects of the prediction of oil and gas potential of the Riphean-Vendian sediments of the Volga-Ural petroleum province]. Sostoyanie $i$ perspektivy neftegazovogo potentsiala Permskogo kraya $i$ prilegayushchikh regionov. Materialy nauchno-prakticheskoy konferentsii, 8-9 November 2006. Perm, 2007, pp.74-85.

4. Bashkova S.E., Bashkov A.N., Karaseva T.V. Osobennosti Volgo-Uralskoy neftegazonosnoy provintsii po glubine pogruzheniya otlozheniy, osvoennykh neftegazodobyvayushchey promyshlennostyu [Features of the Volga-Ural oil and gas province by the depth of immersion of deposits produced by the oil and gas industry]. Geologiya $i$ poleznye iskopaemye zapadnogo urala. Materialy regionalnoy nauchno-prakticheskoy konferentsii. Perm, 2004, pp.136-140.

5. Bashkova S.E., Karaseva T.V. O perspektivakh neftegazonosnosti rifeyskikh otlozheniy severnoy chasti Kamsko-Belskogo progiba [On the oil and gas potential of the Riphean sediments of the northern part of the KamaBelsky trough]. Perm, KamNIIKIGS, 2005, dep. v VIEMS no.1228-mg05.

6. Bashkova S.E., Karaseva T.V. Nekotorye osobennosti protsessov generatsii uglevodorodov $\mathrm{V}$ rifey-vendskikh otlozheniyakh Volgo-Uralskoy neftegazonosnoy provintsii [Some features of the generation of hydrocarbons in the Riphean-Vendian sediments of the Volga-Ural petroleum province] Geologiya $i$ poleznye iskopaemye Zapadnogo Urala. Materialy regionalnoy nauchno-prakticheskoy konferentsii. Perm, 2006, pp.86-89.
7. Belokon A.V. Osobennosti tekhnologii basseynovogo modelirovaniya protsessov neftegazoobrazovaniya i neftegazonakopleniya [Features of the technology of basin modeling of processes of oil and gas formation and oil and gas accumulation]. Perm, KamNIIKIGS, 2004, 10 p. dep. v VIEMS 19 January 2004, no.1180-mg-04.

8. Belokon T.V. Raspredelenie metalloporfirinov $\mathrm{v}$ neftyakh razlichnykh neftegazonosnykh regionov [Distribution of metal porphyrins in the oils of various oil and gas regions]. Geokhimiya, 1987, no.6, pp.877-889.

9. Belokon T.V., Balashova M.M., Gorbachev V.I. Perspektivy dalneyshego izucheniya neftegazonosnosti verkhnedokembriyskikh otlozheniy vostoka Russkoy platformy [Prospects for further study of the oil and gas potential of the Upper Precambrian deposits of the east of the Russian Platform]. Otechestvennaya geologiya, 1994, no.3, pp.3-10.

10. Belokon T.V., Gorbachev V.I., Balashova M.M. Stroenie i neftegazonosnost rifeysko-vendskikh otlozheniy vostoka Russkoy platformy [Structure and oil and gas potential of Riphean-Vendian sediments in the east of the Russian platform]. Perm, Zvezda, 2001, 108 p.

11. Belokon T.V., Kozlov V.I., Dulepov Yu.A., Koblova A.Z., Kozlova E.V. Geokhimiya porod i flyuidov dodevonskikh otlozheniy severo-vostoka Uralo-Povolzhya [Geochemistry of rocks and fluids of the pre-Devonian deposits of the northeast of the Ural-Volga region]. Ufa, 1991, $39 \mathrm{p}$.

12. Belokon T.V., Galkin V.I., Kozlova I.A., Bashkova S.E. Dodevonskie otlozheniya Permskogo Prikamya kak odno iz perspektivnykh napravleniy geologorazvedochnykh rabot [Pre-Devonian deposits of the Perm Prikamye as one of the promising areas of exploration]. Geology, Geophysics and Development of Oil and Gas Fields, 2005, no.9-10, pp.24-28.

13. Korchagina Yu.I., Chetverikova O.P. Metody interpretatsii analiticheskikh dannykh o sostave rasseyannogo organicheskogo veshchestva [Methods of interpretation of analytical data on the composition of dispersed organic matter]. Moscow, Nedra, 1980, $228 \mathrm{p}$.

14. Karaseva T.V., Galkin V.I., Kozlova I.A. Dodevonskie otlozheniya Permskogo Prikamya kak odno iz perspektivnykh napravleniy geologo-razvedochnykh rabot [Pre-Devonian sediments of the Perm Prikamye as 
one of the promising areas of exploration]. Geology, Geophysics and Development of Oil and Gas Fields, 2005, no.9-10, pp.6-15.

15. Karaseva T.V., Denisov A.I., Bashkova S.E. Rifeyskie otlozheniya Volgo-Uralskoy neftegazonosnoy provintsii kak perspektivnyy obekt dlya poiskov uglevodorodov [Riphean deposits of the Volga-Ural oil and gas province as a promising object for hydrocarbon exploration]. Strategiya razvitiya mineralno-syrevogo kompleksa privolzhskogo i yuzhnogo okrugov na 2006 i posleduyushchie gody. Tezisy dokladov nauchnoprakticheskoy konferentsii. Saratov, 2005, pp.76-77.

16. Bazhenova T.K., Bogoslovskiy S.A., Shapiro A.I., Vasileva V.F., Rogozina N.A. Organicheskaya geokhimiya osadochnogo vypolneniya Vychegodskogo progiba (Russkaya plita) i ego geotermicheskaya istoriya [Organic geochemistry of sedimentary discharge of the Vychegodskiy trough (Russian plate) and its geothermal history]. Neftegazovaya geologiya. Teoriya i praktika, 2013, vol.8, no.3, pp.1-31.

17. Maksimov S.P., Lodzhevskaya M.I., Dolenko G.N. et al. Formirovanie zalezhey nefti i gaza na razlichnykh etapakh razvitiya sedimentatsionnykh basseynov [Formation of oil and gas deposits at various stages of development of sedimentation basins]. Moscow, VNIGNI, 1981, 223p.

18. Sharonov L.V. Formirovanie neftyanykh i gazovykh mestorozhdeniy severnoy chasti Volgo-Uralskogo basseyna [Formation of oil and gas fields in the northern part of the Volga-Ural basin]. Vsesoyuznyy nauchno-issledovatelskiy geologorazvedochnyy neftyanoy institut. Kamskiy filial. Perm, Knizhnoe izdatelstvo, 1971, 290 p.

19. Adams D.C., Keller G.R. Precambrian basement geology of the Permian Basin region of west Texas an castern New Mexico: A geophysical perspective. American Association of Petroleum Geologists Bulletin, 1996, vol.80, pp.410-431. DOI: 10.1306/64ED87FA-1724-11D7-8645000102C1865D

20. Armstrong A.K., Wrucke C.T. Depositional environment of the carbonate members of the Middle Proterozoic Mescal Limestone, Apache Group, central and southern Arizona. New Mexico Geology, 1990, vol.12, no. 3,65 p.

21. Bickford M.E., Marsaglia K.M., Whitelaw M.J., Soegaard K. Correlation between Precambrian sequences in the Franklin Mountains Van Horn, West Texas: A progress report, Geological Society of America, Rocky Mountain Section Meeting, Abstracts with Prigrams, 1994, vol.26, pp.4-5.

22. Blount J.G. The geochemistry, petrogenesis, and geochronology of the Precambrian meta-igneous rocks of Sierra Del Cuervo and Cerro El Carrizalillo, Chihuahua, Mexico, Austin, University of Texas, 1993, $242 \mathrm{p}$.

23. Bruhn R.L., Picard M.D., Isby J.S. Tectonics and sedimentology of Uinta Arch, western Uinta Mountains, and Unita Basin. Paleotectonics and sedimentation in the Rocky Mountain Region. Ed. J.A. Petersom, American Association of Petroleum Geologists Memoir 41, 1986, pp.333-352.
24. Callahan D.M. Paleotectonic reconstruction and provenance analysis of the synorogenic Precambrian Hazel Formation, Van Horn, Trans-Pecos Texas, Dallas, University of Texas, 1992, $104 \mathrm{p}$.

25. Collen J.D., Newman R.H. Porosity development in deep sandstones, Taranak Basin. New Zealand. J. Southeast Asian. Reg Sci., 1991, no.5, pp.449-452. DOI: 10.1016/0743-9547(91)90060-B

26. Condie K.C. Chemical composition and evolution of the upper continental crust: contrasting results from surface samples and shales. Chemical Geol., 1993, vol.104, iss.1-4, pp.1-37. DOI: 10.1016/0009-2541(93)90140-E

27. Bethke C.M., Lee Ming-Kuo, Park Jungho. Basin Modeling with Basin2. Release 5.0.1. Hydrogeology Program University of Illinois, 2007, 210 p.

28. Dallmeyer R.D., Grambling J.A., Thompson A.G. Age and characted of Proterozoic polymetamorphism in New Mexico. Society of America Abstracts with Prigrsms, 1990, vol.22, pp.A 113

29. Donnelly T.H., Jackson M.J. Sedimentology and geochemistry of a mid-Proterozoic lacustrine unit from northern Australia. Sediment. Geol., 1988, vol.58, iss.2-4, p. 145-169. DOI: 10.1016/0037-0738(88)90067-X

30. Edgell H.S. Proterozoic salt basins of the Persian Gulf area and their role in hydrocarbon generation. Precam. Res., 1991, vol.54, no.1, pp.1-14. DOI: 10.1016/0301-9268(91)90065-I

31. Garjzzi A.V., Von Bergen D. Stylolitic porosity in carbonates: a critical factor for deep hydrocarbon production. Jow Pert. Yeol, 1987, vol.10, no.3, pp.267-282. DOI: 10.1111/j.1747-5457.1987.tb00946.x

32. Harbour R.L. Precambrian rocks at North Franklin Mountain, Texas. American Association of Petroieum Geologists Bulletin, 1960, vol.44, pp.1785-1792.

33. Huntoon P.W. Proterozoic structural geology of the grand canyon. Grand canyon geology. Eds. S.S. Beus, M. Moralcs, 1990, pp.261-309.

34. Nesbitt H.W., Young G.M. Early Proterozoic climates and plate motions inferred from major element chemistry of lutites. Nature, 1982, vol.299, pp.715-717. DOI: $10.1038 / 299715 \mathrm{a} 0$

35. Reynolds R.C. The concentration of boron in Precambrian seas. GCA, 1965, vol.29, no.1, pp.1-16. DOI: $10.1016 / 0016-7037(65) 90072-4$

36. Taylor T.R. The influens of calcite dissolution on reservoir porosity in Miocene sandstones picaroon. J. Sediment Pert, 1990, vol.60, no.3, pp.322-334. DOI: 10.1306/212F9192-2B24-11D7-8648000102C1865D

37. Vance R.K., Condie K.C. Geochemistry of footwall alteration associated with the early Proterozoic United Verde massive sulfide deposit, Arizona. Economic Geology, 1987, vol.82. no.3, pp.571-586. DOI: $10.2113 /$ gsecongeo.82.3.571

38. Visser W. Burial and thermal history of Proterozoic source rocks in Oman. Precam. Res., 1991, vol.54, no.1, pp.15-36. DOI: 10.1016/0301-9268(91)90066-J

39. Wakelin-King G. Proterozoic play challenges Amadeus basin explorers. Oil and Gas, 1994, vol.92, no.9, pp.52-55. 
40. Polster L.A., Viskovskiy Yu.A., Nikolenko V.A. et al. Istoriko-geneticheskiy metod otsenki perspektiv neftegazonosnosti [Historical-genetic method for assessing the prospects of petroleum potential]. Moscow, Nedra, $1984,200 \mathrm{p}$.

41. Kalmykov G.S. Katagenez i paleotemperatury Permskogo Prikamya i Priuralya [Catagenesis and paleotemperature of Perm Prikamye and Cis-Urals]. Problemy geologii nefti, 1976, no.8, pp.98-112.
42. Kalmykov G.S. Prognoz neftegazonosnosti po stadiyam preobrazovaniya ugolnogo gumusovogo veshchestva. Nauchnoe obosnovanie napravleniy i metodiki poiskovykh i razvedochnykh rabot na neft i gaz v Permskom Prikame [The forecast of oil and gas potential by stages of conversion of coal humus substances. Scientific substantiation of the directions and methods of prospecting and exploration for oil and gas in the Perm Prikamye]. Perm, Permskoe knizhnoe izdatelstvo, 1971, pp.287-294.

\section{Библиографический список}

1. Балашова М.М., Коблова А.3., Проворов В.М. O позднекембрийском нефтегазообразовании на севере Урало-Поволжья // Геология нефти и газа. 1982. - № 9. - С. 40-43.

2. Башкова С.Е., Белоконь А.В. Новые подходы к поискам углеводородов в рифейских отложениях востока Русской платформы // Дегазация Земли: геофлюиды, нефть и газ, парагенезы в системе горючих ископаемых: тез. междунар. конф. М.: ГЕОС, 2006. - С. 46-49.

3. Геолого-геохимические аспекты прогноза нефтегазоносности рифей-вендских отложений ВолгоУральской НГП / С.Е. Башкова, Т.В. Карасева, С.Г. Попов [и др.] // Состояние и перспективы нефтегазового потенциала Пермского края и прилегающих регионов: материалы науч.-практ. конф., 8-9 ноября 2006 г. - Пермь, 2007. - С. 74-85.

4. Башкова С.Е., Башков А.Н., Карасева Т.В. Особенности Волго-Уральской НГП по глубине погружения отложений, освоенных нефтегазодобывающей промышленностью // Геология и полезные ископаемые Западного Урала: материалы регион. науч.практ. конф. - Пермь, 2004. - С. 136-140.

5. Башкова С.Е., Карасева Т.В. О перспективах нефтегазоносности рифейских отложений северной части Камско-Бельского прогиба / КамНИИКИГС. Пермь, 2005. Деп. в ВИЭМС № 1228-мг05.

6. Башкова С.Е., Карасева Т.В. Некоторые особенности процессов генерации углеводородов в рифейвендских отложениях Волго-Уральской НГП // Геология и полезные ископаемые Западного Урала: материалы регион. науч.-практ. конф. - Пермь, 2006. - С. 86-89.

7. Белоконь А.В. Особенности технологии бассейнового моделирования процессов нефтегазообразования и нефтегазонакопления / КамНИИКИГС. - Пермь, 2004. - 10 с. Депонир. в ВИЭМС 19.01.04 г. № 1180-мг-04.

8. Белоконь Т.В. Распределение металлопорфиринов в нефтях различных нефтегазоносных регионов // Геохимия. - 1987. - № 6. - С. 877-889.

9. Белоконь Т.В., Балашова М.М., Горбачев В.И. Перспективы дальнейшего изучения нефтегазоносности верхнедокембрийских отложений востока Русской платформы // Отечественная геология. - 1994. - № 3. C. 3-10.

10. Белоконь Т.В., Горбачев В.И., Балашова М.М. Строение и нефтегазоносность рифейско-вендских отложений востока Русской платформы. - Пермь: Звезда, 2001. - 108 с.
11. Геохимия пород и флюидов додевонских отложений северо-востока Урало-Поволжья / Т.В. Белоконь, В.И. Козлов, Ю.А. Дулепов, А.З. Коблова, Е.В. Козлова. - Уфа, 1991. - 39 с.

12. Додевонские отложения Пермского Прикамья как одно из перспективных направлений геологоразведочных работ / Т.В. Белоконь, В.И. Галкин, И.А. Козлова, С.Е. Башкова // Геология, геофизика и разработка нефтяных и газовых месторождений. 2005. - № 9-10. - С. 24-28.

13. Корчагина Ю.И., Четверикова О.П. Методы интерпретации аналитических данных о составе рассеянного органического вещества. - М.: Недра, 1980. -228 c.

14. Карасева Т.В., Галкин В.И., Козлова И.А. Додевонские отложения Пермского Прикамья как одно из перспективных направлений геологоразведочных работ // Геология, геофизика и разработка нефтяных и газовых месторождений. 2005. - № 9-10. - C. 6-15.

15. Карасева Т.В., Денисов А.И., Башкова С.Е. Рифейские отложения Волго-Уральской НГП как перспективный объект для поисков углеводородов // Стратегия развития минерально-сырьевого комплекса Приволжского и Южного округов на 2006 и последующие годы: тез. докл. науч.-практ. конф. Саратов, 2005. - С. 76-77.

16. Органическая геохимия осадочного выполнения Вычегодского прогиба (Русская плита) и его геотермическая история / Т.К. Баженова, С.А. Богословский, А.И. Шапиро, В.Ф. Васильева, Н.А. Рогозина // Нефтегазовая геология. Теория и практика. - 2013. T. 8, № 3. - C. 1-31.

17. Формирование залежей нефти и газа на различных этапах развития седиментационных бассейнов / С.П. Максимов, М.И. Лоджевская, Г.Н. Доленко [и др.]. - М.: ВНИГНИ, 1981. - 223 с.

18. Шаронов Л.В. Формирование нефтяных и газовых месторождений северной части ВолгоУральского бассейна / Всесоюзный научно-исследовательский геолого-разведочный нефтяной институт. Камский филиал. - Пермь: Кн. изд-во, 1971. - 290 с.

19. Adams D.C., Keller G.R. Precambrian basement geology of the Permian Basin region of west Texas an castern New Mexico: A geophysical perspective // American Association of Petroleum Geologists Bulletin. 1996. - Vol. 80. - P. 410-431. DOI: 10.1306/64ED87FA1724-11D7-8645000102C1865D 
20. Armstrong A.K., Wrucke C.T. Depositional environment of the carbonate members of the Middle Proterozoic Mescal Limestone, Apache Group, central and southern Arizona // New Mexico Geology. - 1990. Vol. 12, № 3. -65 p.

21. Correlation between Precambrian sequences in the Franklin Mountains Van Horn, West Texas: A progress report / M.E. Bickford, K.M. Marsaglia, M.J. Whitelaw, K. Soegaard; Geological Society of America // Rocky Mountain Section Meeting. Abstracts with Programs. 1994. - Vol. 26. - P. 4-5.

22. Blount J.G. The geochemistry, petrogenesis, and geochronology of the Precambrian meta-igneous rocks of Sierra Del Cuervo and Cerro El Carrizalillo. - Chihuahua, Mexico: Austin, University of Texas, 1993. - $242 \mathrm{p}$.

23. Bruhn R.L., Picard M.D., Isby J.S. Tectonics and sedimentology of Uinta Arch, western Uinta Mountains, and Unita Basin // Paleotectonics and sedimentation in the Rocky Mountain Region / Ed. J.A. Petersom; American Association of Petroleum Geologists Memoir 41. - 1986. - P. 333-352.

24. Callahan D.M. Paleotectonic reconstruction and provenance analysis of the synorogenic Precambrian Hazel Formation. - Van Horn, Trans-Pecos Texas: Dallas, University of Texas, $1992 .-104 \mathrm{p}$.

25. Collen J.D., Newman R.H. Porosity development in deep sandstones, Taranak Basin // J. Southeast Asian. Reg Sci. - 1991. № 5. - P. 449-452. DOI: 10.1016/0743-9547(91)90060-B

26. Condie K.C. Chemical composition and evolution of the upper continental crust: contrasting results from surface samples and shales // Chemical Geol. - 1993. - Vol. 104, iss. 1-4. - P. 1-37. DOI: 10.1016/0009-2541(93)90140-E

27. Bethke C.M., Lee Ming-Kuo, Park Jungho. Basin modeling with Basin2. Release 5.0.1. Hydrogeology Program University of Illinois, 2007. -210 p.

28. Dallmeyer R.D., Grambling J.A., Thompson A.G. Age and characted of Proterozoic polymetamorphism in New Mexico // Society of America Abstracts with Prigrsms. - 1990. - Vol. 22. - P. A 113.

29. Donnelly T.H., Jackson M.J. Sedimentology and geochemistry of a mid-Proterozoic lacustrine unit from northern Australia // Sediment. Geol. - 1988. - Vol. 58, iss. 2-4. - P. 145-169. DOI: 10.1016/0037-0738(88)90067-X

30. Edgell H.S. Proterozoic salt basins of the Persian Gulf area and their role in hydrocarbon generation // Precam. Res. - 1991. - Vol. 54, № 1. - P. 1-14. DOI: 10.1016/0301-9268(91)90065-I
31. Garjzzi A.V., Von Bergen D. Stylolitic porosity in carbonates: a critical factor for deep hydrocarbon production // Jow Pert. Yeol. - 1987. - Vol. 10, № 3. P. 267-282. DOI: 10.1111/j.1747-5457.1987.tb00946.x

32. Harbour R.L. Precambrian rocks at North Franklin Mountain // American Association of Petroieum Geologists Bulletin. - 1960. - Vol. 44. - P. 1785-1792.

33. Huntoon P.W. Proterozoic structural geology of the grand canyon // Grand canyon geology / Eds. S.S. Beus, M. Moralcs. - 1990. P. 261-309.

34. Nesbitt H.W., Young G.M. Early Proterozoic climates and plate motions inferred from major element chemistry of lutites // Nature. - 1982. - Vol. 299. P. 715-717. DOI: $10.1038 / 299715 \mathrm{a} 0$

35. Reynolds R.C. The concentration of boron in Precambrian seas // GCA. - 1965. - Vol. 29, № 1. P. 1-16. DOI: 10.1016/0016-7037(65)90072-4

36. Taylor T.R. The influens of calcite dissolution on reservoir porosity in Miocene sandstones picaroon // J. Sediment Pert. - 1990. - Vol. 60, № 3. - P. 322-334. DOI: 10.1306/212F9192-2B24-11D7-8648000102C1865D

37. Vance R.K., Condie K.C. Geochemistry of footwall alteration associated with the early Proterozoic United Verde massive sulfide deposit, Arizona // Economic Geology. - 1987. - Vol. 82, № 3. - P. 571-586. DOI: $10.2113 /$ gsecongeo.82.3.571

38. Visser W. Burial and thermal history of Proterozoic source rocks in Oman // Precam. Res. - 1991. - Vol. 54, № 1. P. 15-36. DOI: 10.1016/0301-9268(91)90066-J

39. Wakelin-King G. Proterozoic play challenges Amadeus basin explorers // Oil and Gas. - 1994. Vol. 92, № 9. - P. 52-55.

40. Историко-генетический метод оценки перспектив нефтегазоносности / Л.А. Польстер, Ю.А. Висковский, В.А. Николенко [и др.]. - М.: Недра, 1984. - 200 с.

41. Калмыков Г.С. Катагенез и палеотемпературы Пермского Прикамья и Приуралья // Проблемы геологии нефти. - 1976. - № 8. - С. 98-112.

42. Калмыков Г.С. Прогноз нефтегазоносности по стадиям преобразования угольного гумусового вещества. Научное обоснование направлений и методики поисковых и разведочных работ на нефть и газ в Пермском Прикамье. Пермь: Пермское книжное изд-во, 1971. - С. 287-294.

Please cite this article in English as:

Bashkova S.E., Karaseva T.V., Kozlova I.A., Bashkov A.N. Modeling the structure and formation of the oil and gas potential of Riphean-Vendian deposits that belong to north-east regions of the Volga-Ural oil and gas province. Perm Journal of Petroleum and Mining Engineering, 2018, vol.18, no.2, pp.104-117. DOI: 10.15593/2224-9923/2018.4.1

Просьба ссылаться на эту статью в русскоязычных источниках следующим образом:

Моделирование строения и формирования нефтегазоносности рифей-вендских отложений северо-восточных районов ВолгоУральской нефтегазоносной провинции / С.Е. Башкова, Т.В. Карасева, И.А. Козлова, А.Н. Башков // Вестник Пермского национального исследовательского политехнического университета. Геология. Нефтегазовое и горное дело. - 2018. - Т.18, №2. - C.104-117. DOI: 10.15593/2224-9923/2018.4.1 